\section{Site quality assessment of degraded Quercus frainetto stands in central Greece}

\author{
Kyriaki Kitikidou ${ }^{(1)}$, Elias Milios ${ }^{(1)}$, Elias Tsirekis ${ }^{(1)}$, Elias Pipinis ${ }^{(2)}$, \\ Athanasios Stampoulidis ${ }^{(1)}$
}

The potential yield of a site is measured by site index, which is defined as the dominant height of a stand at a base age. A site index model for site quality assessment of Quercus frainetto (Hungarian oak) stands in central Greece was developed using a base age of 50 years. Data were collected from 39 temporary sample plots of $10 \times 10 \mathrm{~m}$. Linear regression models widely used in site index studies were fitted to height-age data. The adjusted coefficient of determination $\left(R^{2}{ }_{a d j}\right)$, root mean square error (RMSE), bias, coefficient of determination for the prediction $\left(\mathrm{R}_{\mathrm{pr}}^{2}\right)$ and residual plots were used for the choice of the best-fitting model. The best model was $\hat{H}=-0.231+0.251 A-0.001 A^{2}$, where $\hat{H}$ is the predicted height at age $A$. The guide curve method was adopted in constructing the sites curves, with the chosen model as the guide curve. Based on this curve, the study area was divided into three site quality classes (I to III), with class I representing the best and class III the poorest. Also, the presence of a Simpson's paradox in these analyses is discussed. The results showed that a 50-year-old stand in the study area attained an average dominant height of about 11,8 and $6 \mathrm{~m}$ on site quality classes I, II and III, respectively. The Hungarian oak stands of the present study can be considered very low productivity stands.

Keywords: Guide Curve Method, Hungarian Oak, Simpson's Paradox, Site Quality

\section{Introduction}

Site quality assessment is the evaluation of the natural productive capacity of a forest site for a tree species. Site quality assessment is very important in forest management, because a site could support one species excellently while supporting poorly other species. The oldest and most widely used technique for evaluating site quality or productivity is the site index.

Site index is the average total height of dominant and co-dominant trees at a specified reference or base age (Clutter et al. 1983). It is scarcely affected by various densities and species composition, relatively stable under various thinning intensities and is strongly correlated with volume. The principal uses of site index are: (1) to estimate the

height at any given age from site index; (2) to estimate site index from height at any given age; (3) to stratify forest land into productive classes; and (4) to provide entry to yield tables (Wang \& Payandeh 1995). However, the most common objective of site index investigations is to determine the height development pattern that the stand is expected to follow throughout its life-cycle (Clutter et al. 1983).

Site index models are essential quantitative tools in forest management (Teshome \& Petty 2000). Most of the techniques used to fit site index curves could be considered as special cases of three general development models, namely: (i) the guide curve; (ii) the difference model; and (iii) the parameter prediction method (Clutter et al. 1983). Among

(1) Department of Forestry and Management of the Environment and Natural Resources, Democritus University of Thrace, Pandazidou 193, GR-68200 Orestiada (Greece); (2) Laboratory of Silviculture, Faculty of Forestry and Natural Environment, Aristotle University of Thessaloniki, GR-54124 Thessaloniki (Greece)

@ Kyriaki Kitikidou (kkitikid@fmenr.duth.gr)

Received: Jul 11, 2013 - Accepted: Jan 26, 2014

Citation: Kitikidou K, Milios E, Tsirekis E, Pipinis E, Stampoulidis A, 2015. Site quality assessment of degraded Quercus frainetto stands in central Greece. iForest 8: 53-58 [online 2014-05-12] URL: http://www.sisef.it/iforest/contents/?id=ifor1069-007

Communicated by: Raffaele Lafortezza the various techniques for developing site index curves, the guide curve method has become popular in those cases where repeated measures through time on the same permanent plots are unavailable (Clutter et al. 1983, Nanang \& Nunifum 1999).

Oak forests covers $22.6 \%$ of the total forested area in Greece (Ministry of Agriculture 1992). According to Christensen (1997), Hungarian oak (Quercus frainetto Ten. syn. Q. conferta Kit.) is an important timber species in most mainland Greece, but not in the drier low elevation area in the southern part of the country. Moreover, Bergmeier \& Dimopoulos (2008) refer that in mainland Greece $Q$. frainetto is the species that most frequently dominates in comparison with the other deciduous oaks.

The aim of this work was to obtain site index curves for site quality assessment of degraded Hungarian oak stands in central Greece to be used in the management of current and future Hungarian oak stands.

\section{Materials and Methods}

\section{Study area}

The study was conducted in degraded Hungarian oak stands located in an area of approximately 290 ha (of which 260 are forested) in central Greece ( $38^{\circ} 53^{\prime} \mathrm{N}, 22^{\circ} 03^{\prime} \mathrm{E}$ - Fig. 1). Data were collected at an elevation ranging from 650 to $750 \mathrm{~m}$ a.s.l. The substratum is flysch and the soil texture is loamy sand, clay-loam to loam (Xirogiannis 2001). According to the closest meteorological station (390 $\mathrm{m}$ a.s.1.), the mean annual rainfall is $873 \mathrm{~mm}$ and the mean annual air temperature is $15.16{ }^{\circ} \mathrm{C}$ (Xirogiannis 2001).

In the past, tree branches in some locations of the area were being cut by residents of nearby villages for livestock feeding, while other places were under agricultural cultivation. Nowadays, the main disturbance is grazing; degree of grazing is low to absent, and only in a small part of the area is severe. Silvicultural treatments have not been applied in the area, mainly because of the lack of adequate forest roads in most of the study area.

\section{Experimental design}

Thirty-nine plots $10 \times 10 \mathrm{~m}$ were established randomly in the forested part of the study area, where the degree of grazing is low to absent, and the main canopy trees were considered approximately even-aged (Fig. 1a, Fig. 1b). In each plot, the height of all trees was measured. The tallest dominant tree was cut in each plot. As a result, the 39 sample trees were among the 100 tallest trees per hectare $(100 \mathrm{x}$ plot area $=1$ ha), so they can be used for the site index estimation (Beekhuis 1966). Many of the sample trees are possibly sprout origin. Cross sectional discs were cut from each felled tree at the 
Fig. 1 - (A) Location of the study area (red circle). (B) Wider study area (red rectangle) and approximate location of the experimental plots (yellow squares).

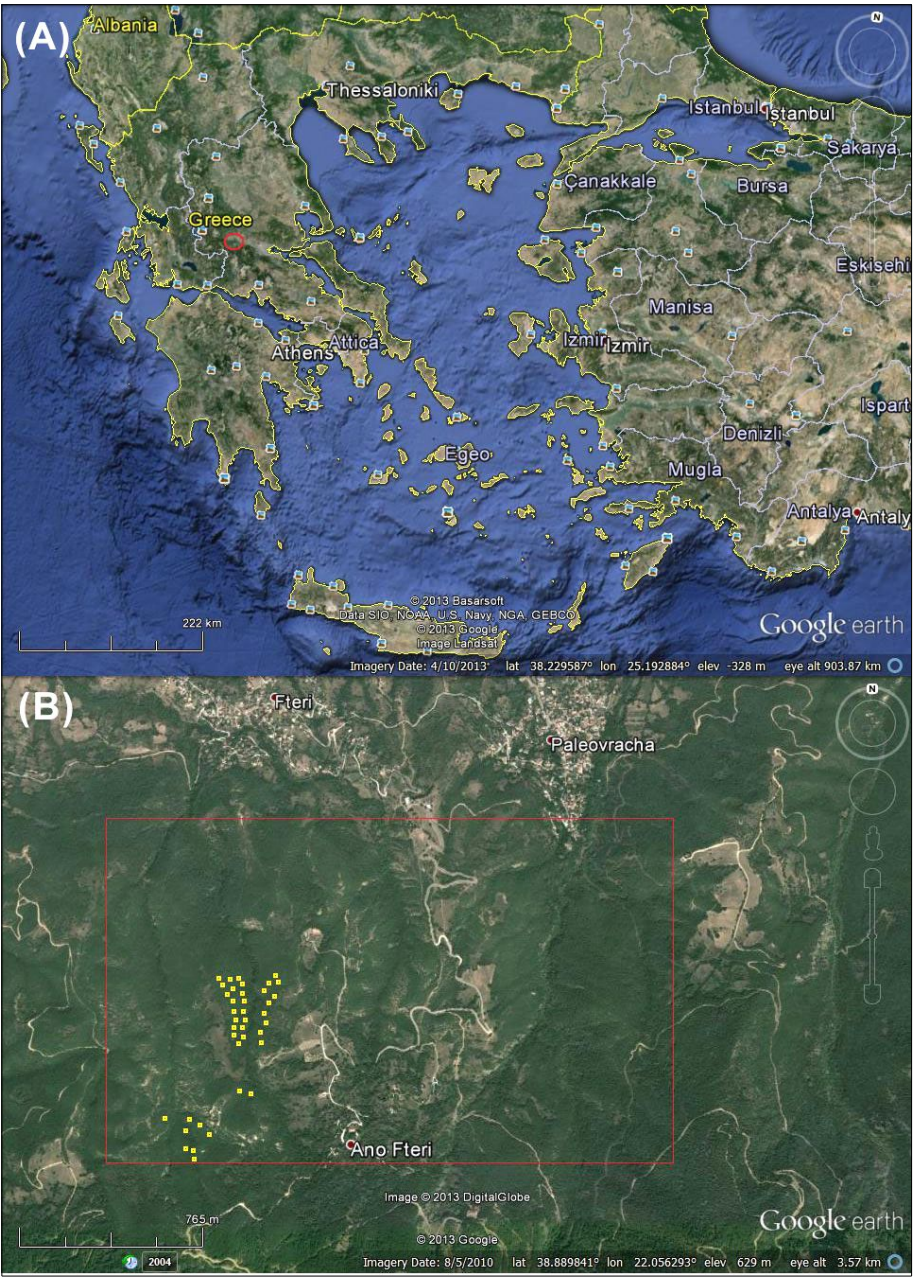

ground level $(\approx 0 \mathrm{~m})$, at the breast height (1.3 $\mathrm{m})$ and at $1 \mathrm{~m}$ intervals. The last disc was collected from the 4-cm bole diameter. Annual growth rings were measured along the mean radius on each cross-sectional disc using the LINTAB ${ }^{\circledR}$ system (RinnTech, Heidelgerg, Germany) and the sofware package TSAP-Win ${ }^{\circledR}$ (Rinn 2003). As for stem analysis, tree height at each age was calculated using a modified version of Carmeans' algorithm (Carmean 1972, Newberry 1991).

\section{Development of growth equations}

Little information is available in the scientific literature on site index for degraded Hungarian oak stands in central Greece; thus the first step was the choice of the appropriate base age. As recommended by several authors (Curtis et al. 1974, Trousdell et al. 1974, Teshome \& Petty 2000), the appropriate base age for site index determination was set to 50 years based on the culmination age of mean annual increment. Among the various techniques for developing site index equations, the guide curve method was adopted in this study since data was obtained from temporary sample plots (Clutter et al. 1983, Nanang \& Nunifum 1999). Three li- near equations commonly used in site index studies were selected from the forestry literature (Carmean 1972, Clutter et al. 1983, Teshome \& Petty 2000) and used for data fitting (eqn. 1 to 3 ):

$$
\begin{gathered}
H=b_{0}+b_{1} A+b_{2} A^{2}+e \\
H=b_{0}+b_{1} A+b_{2} \frac{1}{A}+e \\
H=b_{0}+b_{1} \ln (A)+e
\end{gathered}
$$

where $H$ is the tree height at the age $A, b_{0}, b_{1}$, $b_{2}$ are the regression coefficients to be estimated, and $e$ is the error. The above equations were then compared and the best fitting model was chosen. Numerous criteria for selecting the best model are available; however, since the dependent variable in the above equations was the same, the highest adjusted coefficient of determination $\left(R_{\text {adj }}^{2}\right)$ and the lowest absolute and relative root mean square error (RMSE) were considered appropriate criteria for the selection of the best model. Examination of the residuals was also carried out for assessing the best models by calculating absolute and relative biases
(Vanclay 1994, Soares et al. 1995, Gadow \& Hui 1998). Selection criteria were (eqn. 4 to 8):

$$
\begin{aligned}
& R_{a d j}^{2}=1-\frac{n-1}{n-p} \cdot \frac{\sum_{i=1}^{n}\left(H_{i}-\hat{H}_{i}\right)^{2}}{\sum_{i=1}^{n}\left(H_{i}-\bar{H}_{i}\right)^{2}} \\
& R M S E=\sqrt{\frac{\sum_{i=1}^{n}\left(H_{i}-\hat{H}_{i}\right)^{2}}{n-1}}
\end{aligned}
$$

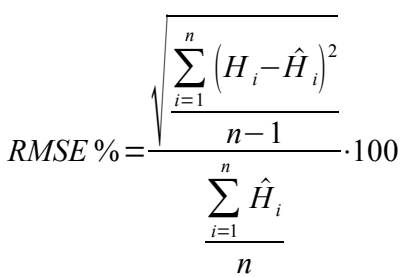

$$
\begin{aligned}
& \text { bias }=\frac{\sum_{i=1}^{n}\left(H_{i}-\hat{H}_{i}\right)}{n} \\
& \text { bias } \%=\frac{\frac{\sum_{i=1}^{n}\left(H_{i}-\hat{H}_{i}\right)}{n}}{\frac{\sum_{i=1}^{n} \hat{H}_{i}}{n}} \cdot 100
\end{aligned}
$$

where $H_{\mathrm{i}}$ is the observed height value for the $i$-th observation, $\hat{H}_{\mathrm{i}}$ is the estimated height value, $\bar{H}$ is the mean of the observed values, $n$ is the number of observations, and $p$ is the number of regression coefficients to be estimated.

The predictive performances of the studied models were also evaluated using prediction errors or PRESS (PREdiction Sum of Squares) residuals. These residuals were calculated by omitting each observation in turn from the dataset, fitting the model to the remaining observations, predicting the response without the omitted observation and comparing the prediction with the observed value (eqn. 9):

$$
H_{i}-\hat{H}_{i,-i}=e_{i,-i}
$$

where $H_{\mathrm{i}}$ is the observed height value and $\hat{H}_{\mathrm{i}, \mathrm{i}}$ is the prediction value obtained by omitting the $i$-th observation $(i=1,2, \ldots, n)$. Each candidate equation has $n$ PRESS residuals associated with it and the PRESS statistics is defined as (Myers 1986 - eqn. $10)$ :

$$
\text { PRESS }=\sum_{i=1}^{n}\left(H_{i}-\hat{H}_{i,-i}\right)^{2}=\sum_{i=1}^{n}\left(e_{i,-i}\right)^{2}
$$

The accuracy of the predictions obtained with the different candidate equations was assessed by computing the coefficient of determination for the prediction (eqn. 11): 


$$
R_{p r}^{2}=1-\frac{\text { PRESS }}{\sum_{i=1}^{n}\left(H_{i}-\bar{H}\right)^{2}}
$$

The interpretation of this coefficient of determination is similar to that described for other similar coefficient, i.e., a value close to 1 indicates high predictive performances for the model considered.

Stands were stratified into three site quality classes, with site quality decreasing from class I to III. Using the predicted height growth trend described by the chosen model (guide curve), anamorphic site index curves were fitted to pass through three different site index classes of I to III. This was accomplished by holding the shape parameters constant and varying the asymptote parameter as necessary to achieve the required dominant height when stand age $(A)$ equals the base age $\left(A_{0}=50\right.$ years). This approach has been successfully used in previous studies (Clutter et al. 1983, Teshome \& Petty 2000).

\section{Results and Discussion}

A summary of the height characteristics of the 39 sample trees used for site index modeling are reported in Tab. 1. Mean total height ranged from $7.2 \mathrm{~m}$ at 38 years to $10.86 \mathrm{~m}$ at 59 years.

The parameters and statistics of the regression models considered (eqn. 1 to 3 ) are presented in Tab. 2. The initial observation was that all the models had high $R_{\text {adj }}^{2}$ and low RMSE and bias. All parameters included in the models were statistically significant, indicating that none of the models was overparametrized. As expected, residuals did not display any significant departure from the normal distribution (Fig. 2). A comparison of the three linear models revealed similar fitting performances, though the model of eqn. 1 showed the lowest RMSE and bias (Tab. 2) and therefore it was selected for the construction of the site index curves for Hungarian oak stands in the study area. The predicting curve from eqn. 1 was within the observed variation of the dominant heightage data (Fig. 3). The site index curves for the study area showed that a 50 -years-old

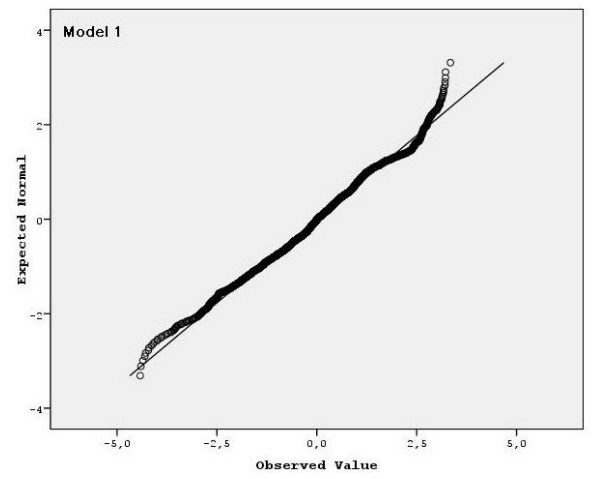

Hungarian oak stand attained an average dominant height of about 11,8 and $6 \mathrm{~m}$ on site classes I, II and III, respectively (Fig. 4).

Simpson's paradox (known also as the $\mathrm{Yu}-$ le-Simpson effect, the reversal paradox, or the amalgamation paradox) is an apparent paradox in which the results of separate groups seem reversed when the groups are combined (Cohen 1986). This paradox is primarily an issue of aggregated statistical analysis where separate groups are analyzed together. In other words, it occurs when a variable has an effect in the same direction within subsets of the data, but when the subsets are combined, the effect vanishes or reverses in direction. The variable used to separate these groups/subsets is called "confounder" (Wagner 1998, Abramson et al. 1992). Cohen (1986) describes the uncertainty principle associated with Simpson's paradox arising when two populations are stratified. The stratification process is undertaken to increase homogeneity among the strata. However, stratification may reverse the apparent rank ordering of the two population means.

In our study, the confounder is the site index, and the Simpson's paradox concerns the total height estimated in contrast to the base age (50 years). Even though models' parameters are correctly estimated, it seems that the estimated height at the age of 50 is lower than the true height measured at an age below 50, and higher than the true height measured at an age above 50 .

Tab. 2 - Estimated parameters and statistics for the three models fitted to temporary plot data for Hungarian oak stands.

\begin{tabular}{ccccccccc}
\hline Model & Coeff. & $\begin{array}{c}\text { Parameter } \\
\text { estimates }\end{array}$ & $\boldsymbol{R}_{\text {adj }}{ }^{2}$ & $\mathbf{R M S E}$ & $\begin{array}{c}\text { RMSE } \\
\mathbf{\%}\end{array}$ & bias & $\begin{array}{c}\text { bias } \\
\%\end{array}$ & $\boldsymbol{R}_{\mathbf{p r}}{ }^{2}$ \\
\hline 1 & $b_{0}$ & -0.231 & 0.799 & 1.414 & 26.093 & $-2.94 \mathrm{E}-13$ & $-5.43 \mathrm{E}-12$ & 0.799 \\
& $b_{1}$ & 0.251 & & & & & & \\
& $b_{2}$ & -0.001 & & & & & & \\
\hline 2 & $b_{0}$ & 0.919 & 0.788 & 1.451 & 26.784 & $1.77 \mathrm{E}-12$ & $3.27 \mathrm{E}-11$ & 0.788 \\
& $b_{1}$ & 0.161 & & & & & & \\
& $b_{2}$ & -1.404 & & & & & & \\
\hline 3 & $b_{0}$ & -3.656 & 0.700 & 1.727 & 31.874 & $1.32 \mathrm{E}-12$ & $2.43 \mathrm{E}-11$ & 0.700 \\
& $b_{1}$ & 2.949 & & & & & & \\
\hline
\end{tabular}
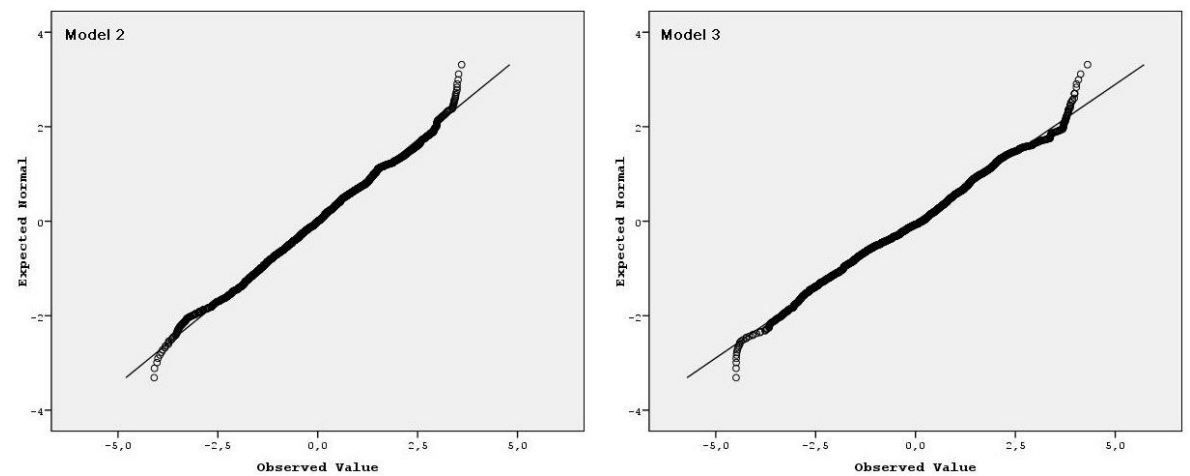

Tab. 1 - Summary statistics of the sample trees (dominant trees) used in site index modeling. (SE): standard error of the mean.

\begin{tabular}{cccccl}
\hline \multicolumn{2}{c}{ Trees } & \multicolumn{5}{c}{ Total height (m) } \\
\hline $\begin{array}{c}\text { Age } \\
\text { (years) }\end{array}$ & Count & Min & Max & Mean & SE \\
\hline 35 & 1 & 9.5 & 9.5 & 9.5 & - \\
38 & 1 & 7.2 & 7.2 & 7.2 & - \\
43 & 1 & 7.5 & 7.5 & 7.5 & - \\
47 & 1 & 8.7 & 8.7 & 8.7 & - \\
50 & 3 & 9.2 & 10 & 9.5 & 0.252 \\
51 & 1 & 7.2 & 7.2 & 7.2 & - \\
52 & 1 & 7.7 & 7.7 & 7.7 & - \\
54 & 7 & 7.2 & 11.5 & 9.31 & 0.489 \\
55 & 1 & 9 & 9 & 9 & - \\
57 & 7 & 6.8 & 10.5 & 8.8 & 0.492 \\
58 & 3 & 6.5 & 10.5 & 7.97 & 1.272 \\
59 & 5 & 7 & 12.5 & 10.86 & 1.002 \\
60 & 1 & 10 & 10 & 10 & - \\
63 & 1 & 9.2 & 9.2 & 9.2 & - \\
64 & 2 & 10.2 & 10.5 & 10.35 & 0.15 \\
66 & 3 & 9.6 & 11.5 & 10.33 & 0.59 \\
\hline
\end{tabular}

Such apparent paradox may also be attributable to a King Kong effect (Makridakis et al. 1998). The King Kong effect was named from a theoretical study on the relationship of weight to height in a sample of gorillas in which one extreme value (i.e., King Kong) is added. The addition of such extreme value to the sample of gorillas skews the height and weight data and affects their correlation. As a result, a weight/height relationship greater

Fig. 2 - Residual Q-Q plots for the three regression models considered in this study. 


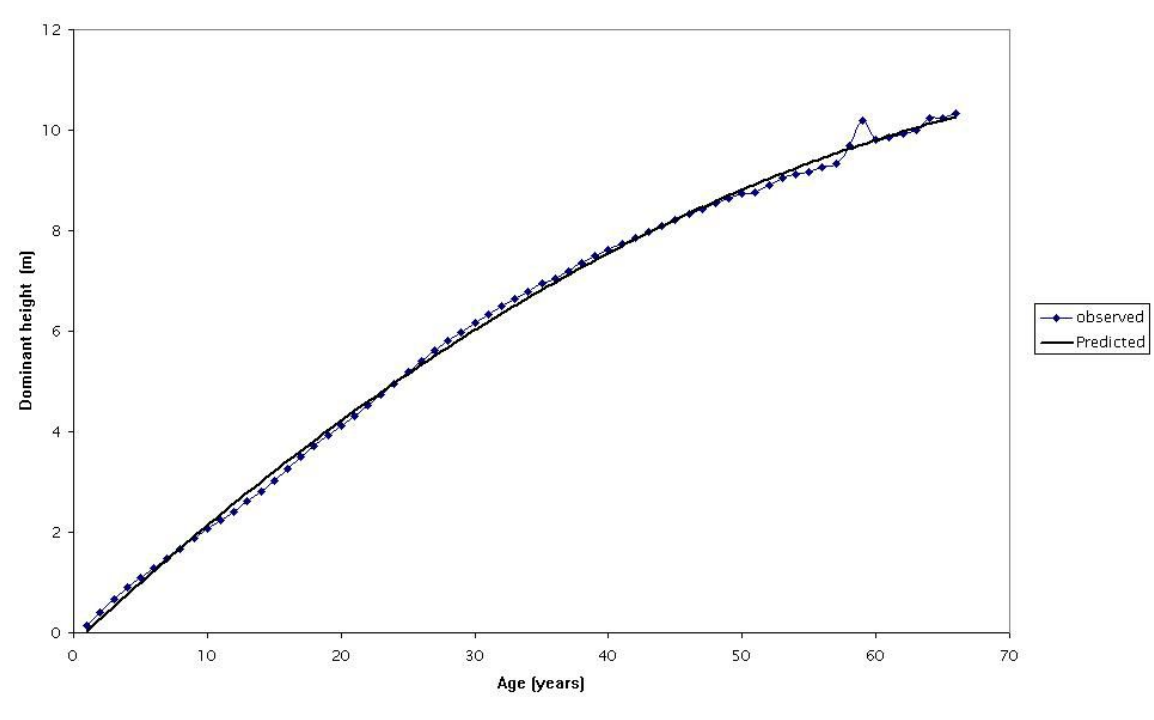

Fig. 3 - Comparison of the observed dominant height-age data and the predicted values obtained using the model from eqn. 1.

than that existing before adding the extreme value is obtained (Makridakis et al. 1998). In our study, the site (arbitrarily defined from the general tree development) could be the King Kong value. Adding this variable a smoother height growth potential of the tree is obtained, i.e., a tree with an estimated height at base age which classifies it in a higher site quality, actually belongs to a lower site quality.

The absence of permanent plots necessitated the use of temporary plot data of different ages. This limitation permitted only the use of the guide curve method for the development of site index models. Therefore, it was assumed that the distribution of plots

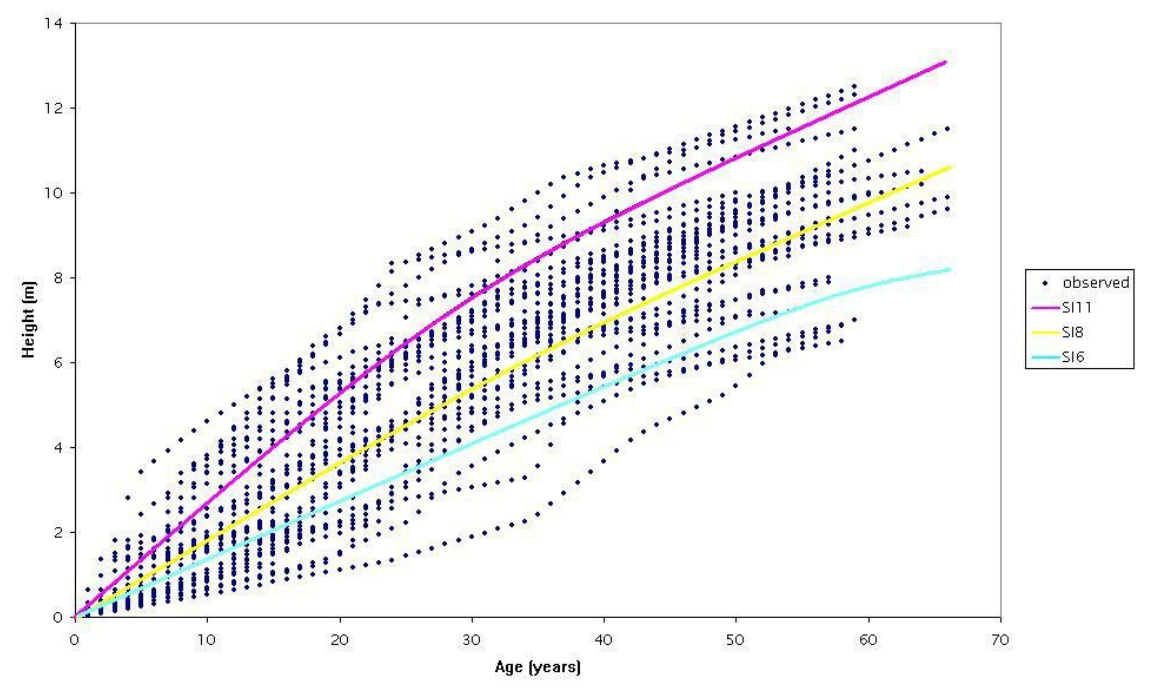

Fig. 4 - Site index curves for Hungarian oak stands constructed using the model of eqn. 1. (SI): Site Index. (SI6), (SI8), (SI11): average height of dominant trees at the age of 50 years on the sites III, II, and I, was 6,8 and $11 \mathrm{~m}$, respectively. the required dominant height value when stand age $(A)$ equals the index age $\left(A_{0}\right)$. The base age of 50 years used for the development of site index curves in the present study seems appropriate, since base age corresponds to the period of completion of rapid growth, i.e., when mean annual increment is culminated (Trousdell et al. 1974).

Fig. 4 presents the site index curves developed for the species under investigation. Areas of good site quality are those characterized by a high height growth (Clutter et al. 1983). The best site quality class was site class I, while the medium and the poorest site quality classes were II and III respectively. This implies that a stand with height development pattern similar to curve SI11 is growing on a better site than a stand with height development pattern similar to curve SI8. A stand with a mean dominant height of about $4 \mathrm{~m}$ at age 15 years is expected to follow the height development pattern exhibited by class I, while a stand with a mean dominant height of about $3 \mathrm{~m}$ at the age of 15 years is expected to follow the height development pattern exhibited by class II. However, there could be a shift in the site index, caused by climatic variation, measurement error, damage to dominant height by diseases and fire, as well as removal of dominant trees through thinning (Teshome \& Petty 2000).

Even though there are more productive sites in adjacent areas, the Hungarian oak stands of the present study are not productive. Tree height growth, even in the best site quality, is very low. Matis (2000), using dominant and codominant trees, presented site index curves for Hungarian oak derived from coppice stands in the University forest of Taxiarchis in Chalkidiki (northern Greece). Tree growth rates were significantly higher as compared with the results of the present study. In particular, he distinguished five site qualities, noting that the tree height is up to $11.72 \mathrm{~m}$ in the $\mathrm{V}$ site quality at the breast height age of 50 years, while in the best (I) site quality trees showed a height of at least $21.68 \mathrm{~m}$. On the other hand, when he distinguished three site qualities, trees of the third (III) site quality at the same breast height age had a height up to $13.93 \mathrm{~m}$, and trees of the best (I) site quality were at least $19.47 \mathrm{~m}$ tall. In Hungarian oak stands from approximately the same area, Smiris et al. (1992), using stem analyses of 15 trees that had the dimensions of the mean bole, noted that the height of the "mean bole" tree was $19.17 \mathrm{~m}$ at the age of 49 years. Smiris et al. (1998), in experimental plots in sprout origin Hungarian oak stands, where different intensity thinnings had been applied, notice that, at the age of 52 years, the mean height of trees was ranging between 14.18 (control plot) and $16.19 \mathrm{~m}$ (light thinning plot). In north-eastern Chalkidiki, Dafis (1966) distinguished 
six site qualities for coppice Hungarian oak stands. Average height of trees of the main stand in the V site quality, at the age of 40 years, was the same as the height of trees, at the age of 50 years, in the best site quality of the present study.

Collecting data for a longer period of time from permanent sample plots may allow site index curves to be validated. Indeed, a good knowledge of growth and yield is necessary for sound forest management plans, especially silvicultural decision-making processes such as time of first and subsequent thinnings. The site index curves developed in this study may be useful in quantifying Hungarian oak growth and yield on various low productivity site conditions. Site index curves may also help as a guide in making thinning decisions for stands of species in analogous low productivity conditions. Among the various methods used to determine the time of first and subsequent thinnings, the dominant height approach is preferred because it reflects site effect more than other methods (e.g., age, basal area and volume methods - Teshome \& Petty 2000).

As for Simpson's paradox, it has been mentioned in several forestry researches (Thomas \& Parresol 1989, Scheiner et al. 2000, Loh 2006, Piñeiro et al. 2006). This can happen due to a shift in the distribution of the stands from a previous survey to a more recent survey, and not from a fundamental decline in tree growth, in case of successive forest inventories. In such a case, we can assume that the shift is due to the cutting in saw timber stands that removed the large mature trees, resulting in a reclassification of the stands in the next inventory (Thomas \& Parresol 1989).

In our study, Simpson's paradox can be a key to understanding the apparent inconsistency between height growth rate per tree and the performance of stand level statistics. Measurements of per tree growth rates over time, when used as a whole for site index curve fitting, may give misleading estimates. Actually, foresters must always recognize the effect that each felled tree may have on the forest level growth. Interpretation of our site index curves development, with the awareness of Simpson's paradox, indicates that results from one region should not be extrapolated to another one too far apart on the basis of equations or graphs showing height growth rate by age class. Analysis of growth data for large areas can be risky, considering that the tree-stand interaction over time is quite composite.

\section{Conclusions}

From the analysis of degraded Quercus frainetto stands in central Greece, we obtained site index curves showing the height development pattern that the stands are expected to follow. These site index curves can be used to quantify the production potential of Hungarian oak in low productivity sites. However, before their application outside the study area, the model must be validated using data from permanent sample plots. Lastly, the comprehension of the Simpson's paradox and a cautious analysis of data can increase our understanding of forest growth rates and stand processes.

\section{Acknowledgements}

We would like to thank the Bodossaki Foundation for the financial support of A. Stampoulidis. We also want to thank the Forest Service of Spercheiada (Greece) for their kind cooperation.

\section{References}

Abramson N, Kelsey S, Safar P, Sutton-Tyrell K (1992). Simpson's paradox and clinical trials: what you find is not necessarily what you prove. Annals of Emergency Medicine 21: 1480-1482. doi: 10.1016/S0196-0644(05)80066-6

Alder D (1980). Forest volume estimation and yield prediction. Volume 2 - Yield prediction. FAO Forestry Paper 22/2, FAO, Rome, Italy, pp. 194.

Beekhuis J (1966). Prediction of yield and increment in Pinus radiata stands in New Zealand. Technical Paper No 49, New Zealand Forest Research Institute, Rotorua, New Zealand, pp. 40.

Bergmeier E, Dimopoulos P (2008). Identifying plant communities of thermophilous deciduous forest in Greece: species composition, distribution, ecology and syntaxonomy. Plant Biosystems 142 (2): 228-254. - doi: 10.1080/112635 00802150357

Carmean W (1972). Site index curves for upland oaks in the Central States. Forest Science 18: 109-120. [online] URL: http://www.ingentaconnect.com/content/saf/ss/1972/00000018/000000 $02 / \operatorname{art} 00004$

Christensen KI (1997). Fagaceae. In: "Flora Hellenica" (Strid A, Tan K eds). Koeltz Scientific Books, Koenigstein, Germany, pp. 40-50.

Clutter J, Fortson J, Piennar L, Brister G, Bailey R (1983). Timber management: a quantitative approach. John Wiley and Sons, New York, USA, pp. 333.

Cohen J (1986). An uncertainty principle in demography and the unisex issue. The American Statistician 40 (1): 32-39. [online] URL: http:// www.ingentaconnect.com/content/saf/fs/1972/00 000018/00000002/art00004

Curtis R, Demars D, Herman F (1974). Which dependent variable in site index height-age regression? Forest Science 20: 74-87. [online] URL: http://www.ingentaconnect.com/content/saf/fs/1 974/00000020/00000001/art00017

Dafis S (1966). Site and yield researches in coppice oak and chestnut forests of North-Eastern Chalkidiki (Northern Greece). Internal Report, Department of Forestry and Natural Resources, Aristotle University of Thessaloniki, Thessaloniki, Greece.

Gadow K, Hui G (1998). Modeling forest deve- lopment. Kluwer Academic Publishers, Dordrecht, The Netherlands, pp. 213. [online] URL: http://books.google.it/books?id=bCHAr1ZR5SIC Loh W (2006). Logistic regression tree analysis. In: "Handbook of Engineering Statistics" (Pham $\mathrm{H}$ ed). Springer, pp. 537-549. - doi: 10.1007 978-1-84628-288-1 29

Makridakis S, Wheelwright S, Hyndman R (1998). Forecasting methods and applications ( ${ }^{\text {rd }}$ edn). John Wiley \& Sons, New York, USA, pp. 642.

Matis K (2000). Height growth and site index curves for Quercus conferta Kit. in the University forest at Taxiarchis, Greece. Geotechnical Scientific Issues 11 (2): 64-76.

Ministry of Agriculture (1992). Results of the first National Forest Inventory of Greece. General Secretariat of Forests and Natural Environment, Athens, Greece, pp. 134.

Myers R (1986). Classical and modern regression with applications. Duxbury Press, Boston, MS, USA, pp. 488 .

Nanang D, Nunifum T (1999). Selecting a functional form for anamorphic site index curve estimation. Forest Ecology and Management 118 : 211-221. - doi: 10.1016/S0378-1127(98)005015

Newberry J (1991). A note on Carmean's estimate of height from stem analysis data. Forest Science 37 (1): 368-369. [online] URL: http://www.ingentaconnect.com/content/saf/fs/1991/00000037 /00000001/art00029

Piñeiro G, Oesterheld M, Batista W, Paruelo J (2006). Opposite changes of whole-soil vs. pools C:N ratios: a case of Simpson's paradox with implications on nitrogen cycling. Global Change Biology 12: 804-809. - doi: 10.1111/j.1365-24 86.2006.01139.x

Rinn F (2003). TSAP-Win user reference manual. RinnTech, Heidelgerg, Germany, pp. 91.

Scheiner S, Cox S, Willig M, Mittelbach G, Osenber C, Kaspari M (2000). Species richness, species-area curves and Simpson's paradox. Evolutionary Ecology Research 2: 791-802.

Smiris P, Aslanidou M, Milios E (1998). Oak (Quercus conferta Kit.) thinnings at Cholomonda, Chalkidiki (Northern Greece). In: Proceedings of the " 8 th $P$ an-Hellenic Conference of the Greek Forestry Society". Alexandroupoli (Greece) 6-8 Apr 1998. Greek Forestry Society, Tessaloniki, Greece, pp. 417-424.

Smiris P, Ganatsas P, Efthymiou G (1992). Forest dynamics of two oak stands under restoration. Scientific Annals of the Department of Forestry and Natural Resources, Aristotle University of Thessaloniki, Greece, vol. 35/2, pp. 607-626.

Soares P, Tomé M, Skovsgaard J, Vanclay J (1995). Evaluating a growth model for forest management using continuous forest inventory data. Forest Ecology and Management 71: 251265. - doi: 10.1016/0378-1127(94)06105-R

Teshome T, Petty J (2000). Site index equation for Cupressus lusitanica stands in Munessa, Ethiopia. Forest Ecology and Management 126: 339347. - doi: 10.1016/S0378-1127(99)00105-X

Thomas CH, Parresol R (1989). Comparing basal 
area growth rates in repeated inventories: Simpson's paradox in forestry. Forest Science 35 (4) 1029-1039.

Trousdell K, Beck D, Lioyd F (1974). Site index for loblolly pine in the Atlantic Central Plain of the Carolina and Virginia. Research Paper SE115, USDA Forest Service, USA, pp. 11.

Vanclay J (1994). Modeling forest growth and yield: applications to mixed tropical forests.
CABI Publishing, Wallingford, UK, pp. 336.

Wagner C (1998). Simpson's paradox in real life. American Statistician 36: 46-48.

Walters D, Gregoire T, Burkhart H (1989). Consistent estimation of site index curves fitted to temporary plot data. Biometrics 45 (1): 24-33. doi: $10.2307 / 2532032$

Wang Y, Payandeh B (1995). A base-age invariant site index model for aspen stands in north central Ontario. Forest Ecology and Management 72: 207-211. - doi: 10.1016/0378-1127(94)034 64-8

Xirogiannis A (2001). Management plan of state oak forests at North-Western Vardousia mountains (central Greece), for the period 2000-2009. Forest Service, Sperchiada, Greece, pp. 322. 